\title{
THE MACRO-REGIONALISATION OF THE WESTERN MEDITERRANEAN, BETWEEN RENEWAL AND UNCOMPLETION
}

\author{
Thomas Perrin \\ University of Lille, Laboratory TVES \\ Univ. Lille, UR 4477 - TVES - Territoires Villes Environnement \& Société, F-59000 Lille: France \\ thomas.perrin@univ-lille.fr
}

\begin{abstract}
Although there is no 'proper' macro-regional strategy of the European Union for the Western Mediterranean, different works have, for decades, pointed out various factors of macro-regional coherence of this area, including many organisations and schemes of cooperation. After presenting the conceptual framework used to address the theme, we characterise the case and indicate the state of macro-regional cooperation in the area. Then we discuss the variables that contribute to this cooperation, and those that limit it. This case study sheds light on how macro-regionalisation, by combining a trans-meso scale and a post-complex rationale, induces a renewal of spatial references and planning policies in the European Union. It opens perspectives for the future programming period of territorial cooperation.
\end{abstract}

Keywords: European Union, macro-region, macro-regionalisation, territorial cooperation, western Mediterranean.

\section{Introduction}

This article deals with territorial cooperation in the western Mediterranean. The objective is to analyse the dynamics of cooperation and discuss to what extent they induce the construction - if not the constitution - of a macro-region of the European Union (EU), with a specific reference to the macro-regional strategies that the EU set up since 2009 around the Baltic Sea, the Danube basin, the Adriatic and Ionian Seas and the Alpine space (Gänzle \& Kern, 2016; Boulineau, 2017; Zaucha, Pyć, Böhme, Neumann \& Aziewicz, 2020). These strategies target better coordination and interaction between the different territorial cooperation schemes - regional, national, European - in the same macro-region, in order to jointly respond to common development and spatial planning issues: climate change, pollution, transport networks and infrastructures, economic synergies or migratory flows, for example. They are not expected to create a new programme or a new administrative level, but rather to define strategic guidelines from negotiated themes and priorities, which will better rationalise and operationalise the existing instruments. The process must involve the various stakeholders: state and sub-state agents, private and public bodies, non-governmental organisations. We find a similar approach, both in terms of scale and methodology, in the regional sea basin strategies that the EU coordinates for the Baltic Sea, the Black Sea, 
the Mediterranean Sea, the North Sea, the Atlantic Ocean or the Arctic Ocean. However, sea basin strategies are in general less formalised nor structured than macro-regional ones. In some areas both strategies converge and in others we only find sea basin strategies (Fig. 1).

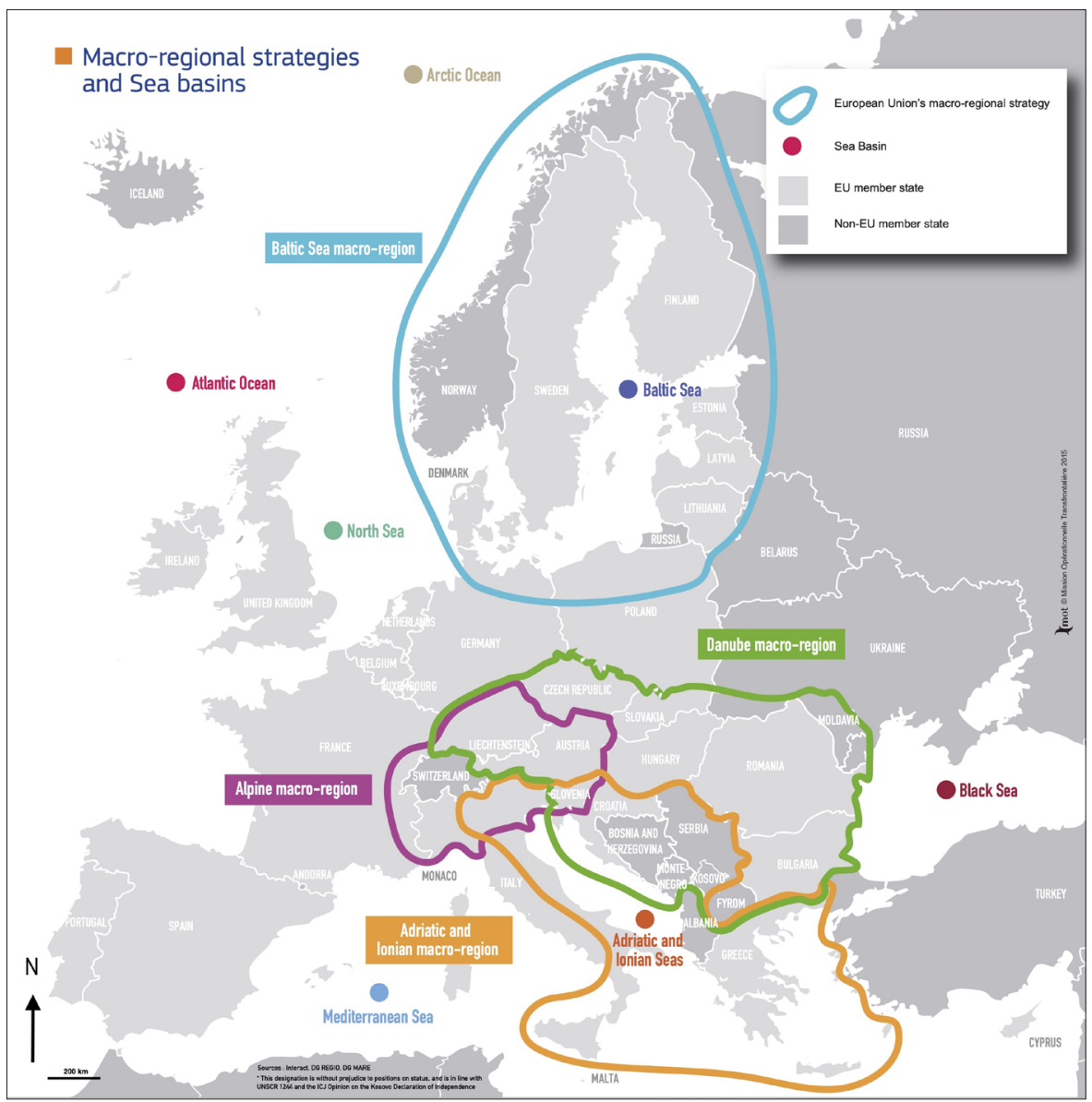

Figure 1. Macro-regional and sea basin strategies in the EU Source: Wassenberg, Reitel, Peyrony and Rubió (2015, p.47).

Although a significant amount of academic literature, institutional reports and specialised events address these modalities of European territorial cooperation ${ }^{1}$, they remain rather confidential outside the circles of interested experts or involved professionals. Moreover, macro-regionalisation is a multifaceted phenomenon that encompasses various and sometimes overlapping structures and processes. It is linked to other complex and diverse territorial and spatial dynamics and concerns several policy fields.

Various studies identify the western Mediterranean as a dynamic and coherent European macro-region. Territorial cooperation develops at many scales in the area, including the macro-regional

\footnotetext{
${ }^{1}$ In 2010 the president of the French region Provence-Alpes Côte d'Azur mentioned a 'macro-regional fever' (Boulineau, 2017, p.95). For instance, just EU institutions produced or commissioned 12 deliverables on the topic in the period 2009-2019: reports and official statements, studies, policy papers, workshop.
} 
level. The area also includes an 'external' dimension of cooperation within the EU Southern and Cross-Border Neighbourhood Policy and such a dimension characterise most of the macro-regional strategies so far. However, no macro-regional strategy sensu stricto exists for the area. It is therefore a particularly interesting case to address macro-regionalisation and analyse its various implications and outputs for regional planning, from territorial projections to policy implementation, and to discuss the outlooks, as well as the hindrances to this mode of territorial cooperation.

The methodology combines documentary analysis and fieldwork. The documentary corpus is based on the academic literature and technical and political documentation, which concerns both macro-regions and macro-regionalisation in general, and the western Mediterranean in particular, including previous works by the author. The literature review led to the elaboration of the analytical framework that has been confronted with the concrete situation on the field. Fieldwork consisted of interviews of targeted actors (7) who work in state, regional and EU offices in relation with macro-regional dynamics in the western Mediterranean (Generalitat de Catalunya, DG Regio, DG Mare and DG Near, Région Occitanie, Secretariat General for the Sea and Ministry of Foreign Affairs in France). Direct participation in key events or meetings related to the topic and the case provided additional and updated data ${ }^{2}$.

\section{Macro-regionalisation in Europe: context and framework of analysis}

Although the launching of EU macro-regional strategies represents a 'critical juncture' to institutionalise this type of territorial cooperation (Dühr, 2018), other mechanisms already existed at a corresponding spatial scope (see Table 1): the so-called 'sub-regional' organisations like the Benelux, the Visegrad Group; the interregional groupings or the European Interreg programmes of the 'transnational' strand launched in the 1990s. Whereas sucb-regional unions are based on traditional inter-state diplomatic arrangements, other types of macro-regionalisation progressively involved a more complex governance framework and a spatial approach that transcends state borders, an evolution that paralleled the advancement of European policies and schemes for territorial cooperation (Medeiros, 2013, 2018). We can also notice that North American researchers elaborated the concept of 'mega-regions', which echoes the European macro-regional approach, especially in terms of scale, even though both macro and mega regionals units have completely different bases (Florida, Gulden \& Mellander, 2008; Seltzer \& Carbonell, 2011, p.243-267; Boix \& Marull, 2016) (Fig. 2) .

\footnotetext{
${ }^{2}$ Macro-regions in the European Union. State of the art, Mediterranean perspective, international seminar Borders and Cross-Border Cooperation in Europe, Barcelona UAB, May 10 ${ }^{\text {th }}$ 2019; Dinàmiques macro-regionals en la Mediterrània occidental: cap a una cooperació territorial renovada, Societat Catalana de Geografia, Barcelona, February $11^{\text {th }}$ 2019; La coopération macro-régionale en Méditerranée: défis, opportunités, perspectives, Forum MedCat, Barcelona, February $4^{\text {th }}$ 2019, The Western Mediterranean. A (what) potential EU macro-region? ISA Annual Convention, April $5^{\text {th }}$ 2018, San Francisco; and attendance to the workshop Potential role of EU macroregional strategies post-2020, European Week of Regions and Cities, $11^{\text {th }}$ October 2017.

${ }^{3}$ Mega-regions are identified with basic urban planning and development criteria: land-use, inferred from the intensity of night-time lighting captured by satellite, which also indicates the links and interactions between urbanized areas. This criterion is cross-referenced with deductions of gross domestic product of these megaregions, in order to produce a ranking and show the economic potential of these territorial complexes.
} 


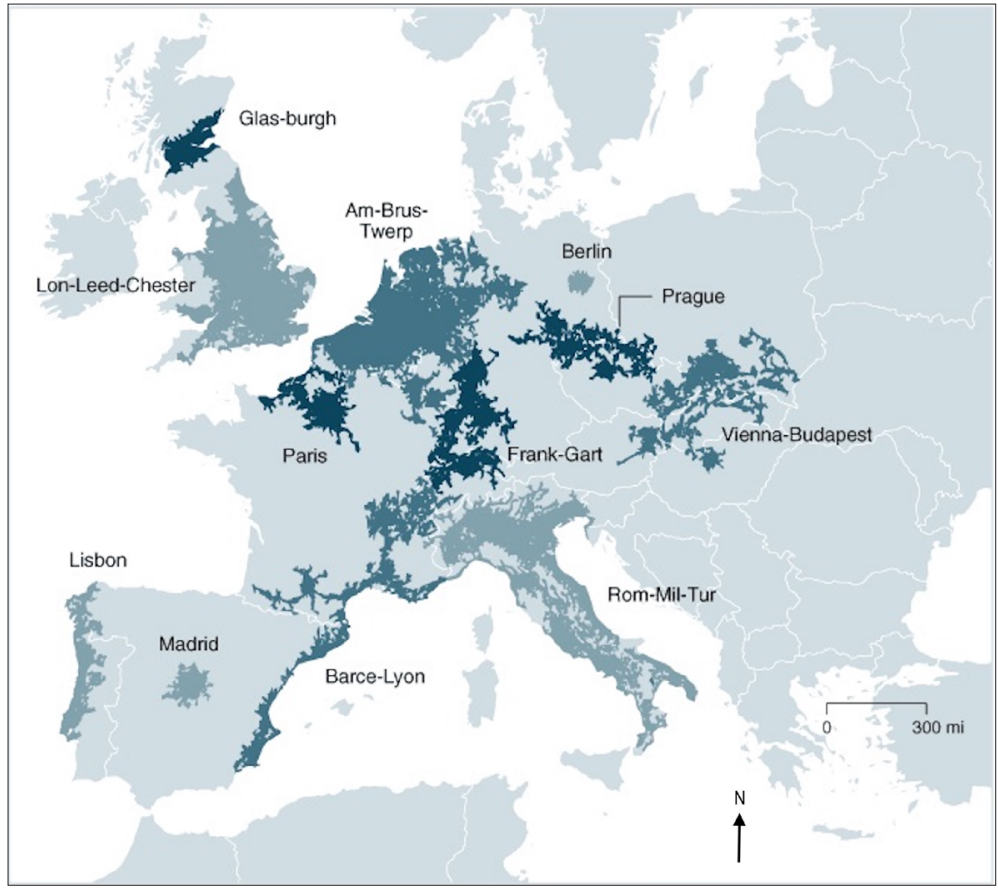

Figure 2. Mega-regions in Europe Source: Gulden and Morris (2020).

Table 1. Typology of macro-regionalisation in Europe

\begin{tabular}{|c|c|c|c|}
\hline Initiative & $\begin{array}{l}\text { Main public } \\
\text { stakeholders }\end{array}$ & Spatial/territorial delineation & Example \\
\hline $\begin{array}{l}\text { Sub-regional } \\
\text { unions }\end{array}$ & States & $\begin{array}{l}\text { Fixed } \\
\text { State borders }\end{array}$ & $\begin{array}{l}\text { Benelux, Visegrad group, Nordic } \\
\text { councils }\end{array}$ \\
\hline $\begin{array}{l}\text { Interregional } \\
\text { grouping }\end{array}$ & Sub-state authorities & $\begin{array}{l}\text { Fixed } \\
\text { Sub-state borders }\end{array}$ & $\begin{array}{l}\text { Geographical commissions of } \\
\text { the Conference of Peripheral } \\
\text { Maritime Regions }\end{array}$ \\
\hline $\begin{array}{l}\text { INTERREG } \\
\text { transnational } \\
\text { programmes }\end{array}$ & $\begin{array}{l}\text { EU } \\
\text { States and sub-state } \\
\text { authorities }\end{array}$ & \begin{tabular}{|l} 
Fixed \\
European nomenclature NUTS
\end{tabular} & $\begin{array}{l}\text { North-West Europe, Adriatic- } \\
\text { lonian }\end{array}$ \\
\hline $\begin{array}{l}\text { Macro-regional } \\
\text { strategies }\end{array}$ & $\begin{array}{l}\text { EU } \\
\text { States and sub-state } \\
\text { authorities }\end{array}$ & $\begin{array}{l}\text { Mixed } \\
\text { State or sub-state borders, but } \\
\text { discourse on variable/adaptable } \\
\text { delimitation depending on the } \\
\text { policy objective or project }\end{array}$ & $\begin{array}{l}\text { Strategy for the Alpine Region, } \\
\text { Danube strategy }\end{array}$ \\
\hline $\begin{array}{l}\text { Sea basin regional } \\
\text { strategies }\end{array}$ & $\begin{array}{l}\text { EU } \\
\text { States and sub-state } \\
\text { authorities }\end{array}$ & $\begin{array}{l}\text { Mixed } \\
\text { State or sub-state borders, but } \\
\text { discourse on variable/adaptable } \\
\text { delimitation depending on the } \\
\text { policy objective or project }\end{array}$ & Atlantic, North Sea \\
\hline
\end{tabular}

Source: own elaboration. 
In spite of their differences, these developments show that such a trans-meso scale, both transnational and intermediate, is relevant to plan and develop territorial ensembles that are distributed between different national, state, sub-state or supra-national authorities but are linked by flows and interactions that surpass traditional borders. This is particularly the case in a transnational organisation like the EU. In the proposal for the 2021-2027 territorial cooperation programmes the European Commission (EC) asks to better align territorial cooperation funds and programmes with existing macro-regional and sea basin strategies, and the Council and the Parliament take similar position ${ }^{4}$. In parallel the European planning observatory ESPON supports the creation of a spatial monitoring instrument for macro-regions (project European and Macro-regional Territorial Monitoring Tool).

On a theoretical level, the issues and processes of macro-regionalisation are representative of a territorial post-modernity, both in terms of planning visions and actions (Table 2) (Perrin, 2020). Macro-regional arrangements illustrate the concept of state rescaling (Brenner, 2004), which describes how the processes of devolution towards 'micro' sub-state regions and the participation into 'macro' supra-state regions, such as the EU, reshape the geography and distribution of state power, without necessarily weakening it. Macro-regionalisation also conveys a relational or associative approach of regions and regional planning, which refers to the implementation of evolving and tailor-made 'project territories' to address specific questions (Seltzer \& Carbonell, 2011, p.1011; Jones \& Paasi, 2013). The notions of soft-spaces or soft planning support this approach in dealing with the flexible and variable delimitation of planning spaces depending on the projects and on the involved partners (Allmendinger, Chilla \& Sielker, 2014). In a similar view, the concept of interterritoriality (Vanier, 2008) posits the intertwining between various 'lived' territories - residential, professional, recreational or service territories - and the perimeters of democratic representation and policy decision. This situation calls for cooperative arrangements to better combine fixed territorial policies with variable territorial usages. Relational, soft, or interterritorial views on regional planning can be found in the dominant discourses on EU macro-regional and sea basin strategies.

Due to this multi-stakeholder and cooperative nature, macro-regionalisation also provides empirical cases of multi-level governance systems that articulate different policy agendas at different political and territorial scales (Albrechts, Healey \& Kunzmann, 2003; Leloup, Moyart \& Pecqueur, 2005). A key feature of macro-regional arrangements is their cooperative dimension and the capacity of the stakeholders to adjust their interests in the perspective of joint decisions. This includes the relations between cross-border organisations or Euroregions within the same macro-region, or relations between territorial authorities and governmental departments.

Finally, macro-regionalisation contributes to spatial and territorial Europeanisation (Bellini \& Hilpert, 2013; Boulineau, 2017). The definition and functioning of most macro-regional arrangements are influenced by the visions and methods of the EU. They promote alternative governance and their objective is to harmonise positions and policies under a common umbrella, focused on European priorities. Furthermore, the mapping of macro-regions can influence European meta-geography, the spatial references by which people organise their perception and knowledge of the world. Macro-regionalisation draws Small Europes Petites Europes (Small Europes) with distinct borders than those of the member states (Dühr, 2018).

\footnotetext{
${ }^{4}$ See European Parliament resolution of 16 January 2018 on the implementation of EU macro-regional strategies (2017/2040(INI)) and Council conclusions of 21 May 2019 on the implementation of EU Macro-Regional Strategies (ST 9101/2019).
} 
Table 2. Analytical framework of macro-regionalisation

\begin{tabular}{|l|l|l|}
\hline \multirow{2}{*}{ Concept / approach } & \multicolumn{1}{|c|}{ Effect / implication for regional planning } \\
\cline { 2 - 3 } & \multicolumn{1}{|c|}{ Projection / vision } & \multicolumn{1}{c|}{ Policy / action } \\
\hline State rescaling & $\begin{array}{l}\text { Transformation of state capacity 'up and down' } \\
\text { Renewal of regionalism and regionalisation 'micro \& macro' }\end{array}$ \\
\hline $\begin{array}{l}\text { Relational regions / soft } \\
\text { spaces }\end{array}$ & $\begin{array}{l}\text { Ad-hoc and non-fixed delimitations, } \\
\text { evolving and tailor-made project } \\
\text { territories }\end{array}$ & $\begin{array}{l}\text { Conjunction \& coordination of diverse } \\
\text { stakeholders at different levels to achieve } \\
\text { a common project/policy }\end{array}$ \\
\hline Interterritoriality & $\begin{array}{l}\text { Interlocking and hybridisation between } \\
\text { territories of daily life and democratic } \\
\text { representation }\end{array}$ & $\begin{array}{l}\text { Conjunction \& coordination of diverse } \\
\text { stakeholders at different levels to achieve } \\
\text { a common project/policy }\end{array}$ \\
\hline Multi-level governance & $\begin{array}{l}\text { Promotion of EU policy methods and } \\
\text { priorities }\end{array}$ \\
\hline Europeanisation & $\begin{array}{l}\text { Re-cartography: promotion of a renewed } \\
\text { meta-geography }\end{array}$ & \multicolumn{1}{|c|}{ - } \\
\hline
\end{tabular}

Source: own elaboration.

The effects of macro-regionalisation on regional planning can thus be analysed in terms of visions or projections - spatial effects - and in terms of territorial action - policy effects. We applied this analysis framework to the case of the western Mediterranean, in order to see whether the features and dynamics of territorial cooperation of the area signal a macro-regionalisation process.

\section{The western Mediterranean: macro-regional features}

There exist several interpretations of the western Mediterranean, depending on the variables used to define it, allowing also variable denominations (Courtot, Daviet \& Joannon, 1994; Rivière, 2005; Durà-Guimerà \& Oliveras-González, 2013). Some of these relate to territorial projections by the EC and to operations of territorial marketing by the authorities of the area. However, beyond this performative dimension, several sources converge to draw an objective mapping of this macro-region.

At the European level, most of the works distinguish between, on one hand, an extended version of a Mediterranean Arc that encompasses the regions, mainly coastal, from Andalusia in southern Spain to Sicily in southern Italy and, on the other hand, a core western Mediterranean that runs from the Valencian Community to Tuscany and links 'three economic regions and their areas of influence: the Catalonia-Valencia axis, the Rhône axis and Northern Italy' (Durà-Guimerà \& Oliveras-González, 2013, p.108). This core macro-region is structured by the metropolitan axes Genoa-Marseille-Barcelona-Valencia on the coast and Lyon-Toulouse-Turin inland. It is sometimes referred to as the 'North-western Mediterranean Arc', or 'Latin Arc', without, once again, one name taking precedence over the other (Fig. 3).

In his reflections on the conceptual map of Europe, the comparative politist Stein Rokkan pointed out that Catalonia, the regions along the Rhine-Rhone axis and Northern Italy belong to an economically and commercially dynamic 'Europe of city states' (Seiler, 2004). And despite temporal and socio-political uncertainties, geo-history can provide elements to assess the macro-regional profile of a given territory... and to motivate it (Perrin, 2019): 'pre-existing common historical and cultural heritages of territories included within macro-regions [can] serve as a useful narrative for a renewed macro-regional epos in cultural terms' (Gänzle \& Kern, 2016, p.9). In the western Mediterranean, similar socio-cultural orientations, in particular the close and relatively well-shared linguistic capacities, are considered to be potential assets for macro-regional cooperation (Nagler, 2013, p.49-50). 


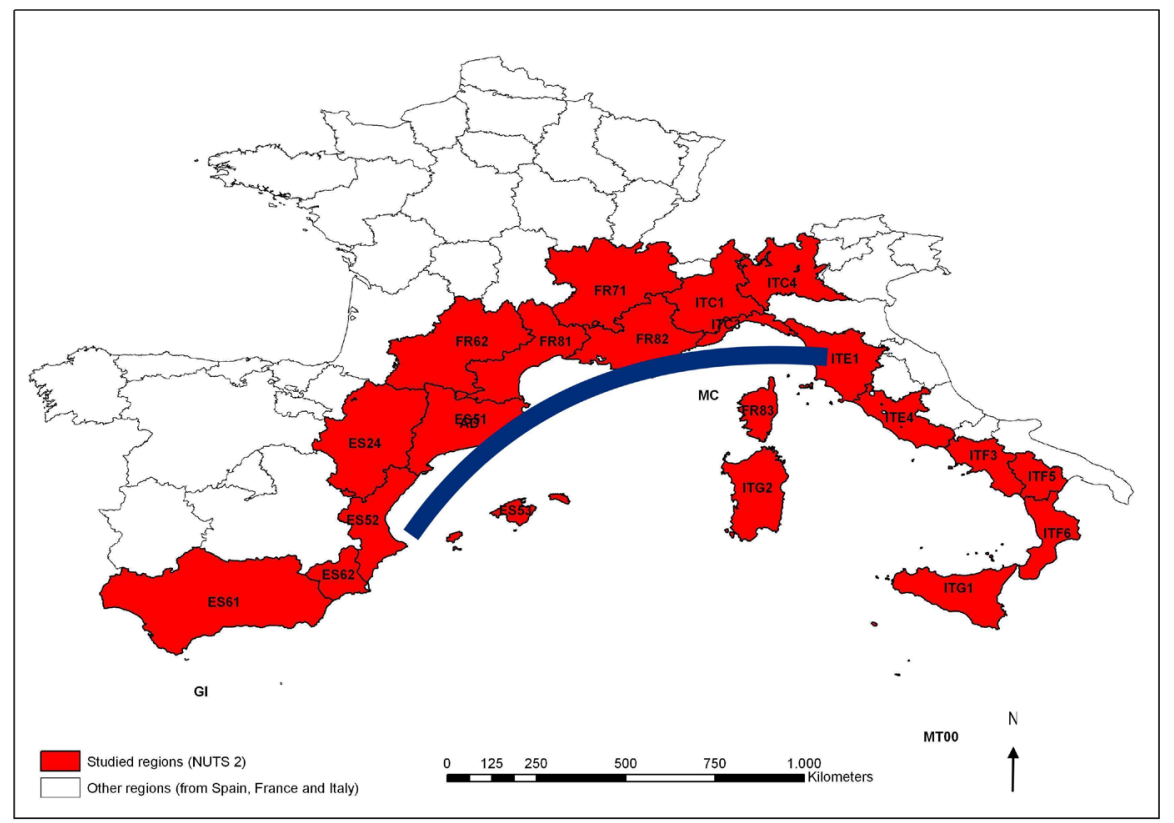

Figure 3. The western Mediterranean, extended version and core area Source: Durà-Guimerà and Oliveras-González (2013, p.102).

In the 1990s, several studies on European spatial planning highlighted this area and its potential, particularly in the nodal zone. Roger Brunet and the GIP Reclus identified a Nord du Sud (North of the South) as a structuring space of the EU (Brunet, 1989). The Europe 2000 by the EC report points to a 'second important centre of development extending from the prosperous regions of southern Germany and northern Italy westwards to rapidly growing parts of southern France and the areas around Barcelona and Valencia' (CEC, 1991, p.13). Then an INTERREG transnational cooperation programme is created for the western Mediterranean, even though from 2007 a unique programme will concern the whole Mediterranean (Dühr, 2018). Other works refer to a European 'sun belt' or 'golden banana' (Lever, 1999, p.1042) 5 . Similar approaches position the western Mediterranean at the heart of a 'fun belt' stretching from the Pyrenees to the Alps, including ski resorts and 'trendy seaside resorts in the Balearic Islands, the Riviera', a 'European California' (Baudelle, Guy \& Ollivro 2002, p.130; Perrin, 2015). In the same vein, North American geographers identified a 'Barce-Lyo mega-region' or 'Euro-Sunbelt mega-region' that stretches from Barcelona to Marseilles and then Lyon. It has a population of about 25 million and ranks $16^{\text {th }}$ and $11^{\text {th }}$ in the world in terms of population and wealth respectively (Florida et al., 2008; Boix \& Marull 2016; see Fig. 2). Even if the economic crisis from 2008 was particularly damaging in the regions of Southern Europe, according to Eurostat data several regions of the nodal western Mediterranean still have a GDP per capita close to, or above, the European average, while in other parts of the Mediterranean the differences are more significant: in the south of Italy and of Spain and in the Eastern Mediterranean

\footnotetext{
${ }^{5}$ The geographical concept of 'sun belt' depicts regions combining a pleasant living environment, proximity to remarkable natural spaces, sunshine and economic dynamism based in particular on research, innovative technologies and revenues generated by tourism. It was originally forged in the 1970 s in reference to the southern USA macro-region running from California to Florida.
} 
in particular. These regions also benefit from relatively dynamic demographics in their country or in Europe, despite a less favourable trend in the Italian regions (Eurostat, 2019).

According to these works and data, the western Mediterranean combines locational advantages, efficient economic sectors and an attractive environment and quality of life. The area is relatively easily linked to the central growth area of Europe or 'European backbone' zone, formerly known as the European 'blue banana' according to the work of Roger Brunet. And socio-economic flows confirm specific linkages within this macro-region (Nagler, 2013).

Despite variations in the definition and conception of this space, several EU policy documents recognise that, given the geo-historical, spatial and socio-political reality of the region, there can only be several macro-regional strategies in the Mediterranean (EESC, 2012; EP, 2012, 2015). In this perspective, the strategy for the Adriatic and Ionian macro-region (EUSAIR) applies to the central Mediterranean macro-region. Moreover, following the logic of soft-spaces, the western Mediterranean is not limited to the northern shore of the Mediterranean. One of the added values of this macro-region can be to strengthen the links and the cooperation with the coastal regions of Morocco, Algeria and Tunisia and their urban agglomerations, which participate in the Southern European Neighbourhood Policy. Yet, even though since the first representations of this area in the 1990s, its function of interface between Europe and the rest of the Mediterranean was highlighted, sometimes pointing out stronger links towards the Southern Mediterranean (Fig. 4), the reality is more complex and sensitive (Scott, Celata \& Coletti, 2019), as we can see in the current developments in the area.

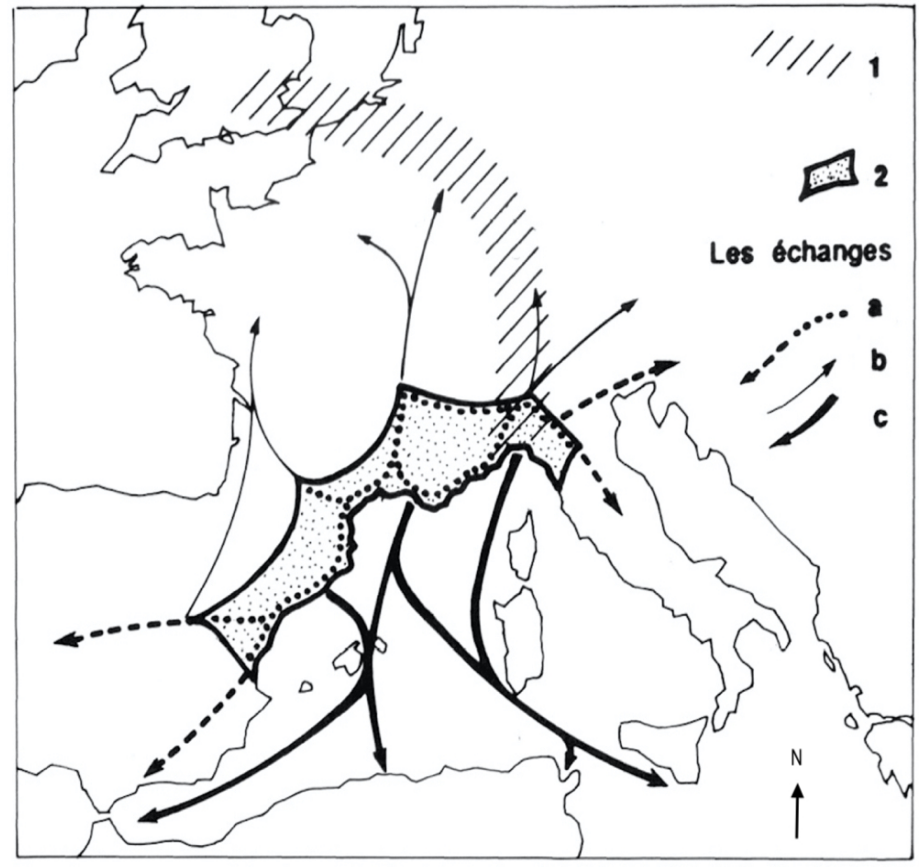

Figure 4. Mega-regions in Europe Source: Gulden and Morris (2020). 


\section{The state of the cooperation: stakeholders and organisation}

The western Mediterranean includes many territorial cooperation structures and initiatives. They can be found at all levels. At the pan-Mediterranean inter-state level the UN Barcelona Convention has several regional activity centres with in the western Mediterranean the Plan Bleu, based in the French technology park Sophia-Antipolis ${ }^{6}$. The Union for the Mediterranean (UfM) for its part brings together the 28 member states of the EU and 15 Mediterranean partner countries. At the sub-state level we find around hundred cooperative organisations, the distribution of which shows a significant involvement of the territorial authorities located in the core western Mediterranean (Durà-Guimerà \& Oliveras-González, 2013) (Fig. 5). An analysis based on the INTERREG programmes underlines that the region is, together with the Baltic Sea, one of the most integrated and coherent macro-regions from the point of view of territorial cooperation (Nagler, 2013, p.38)

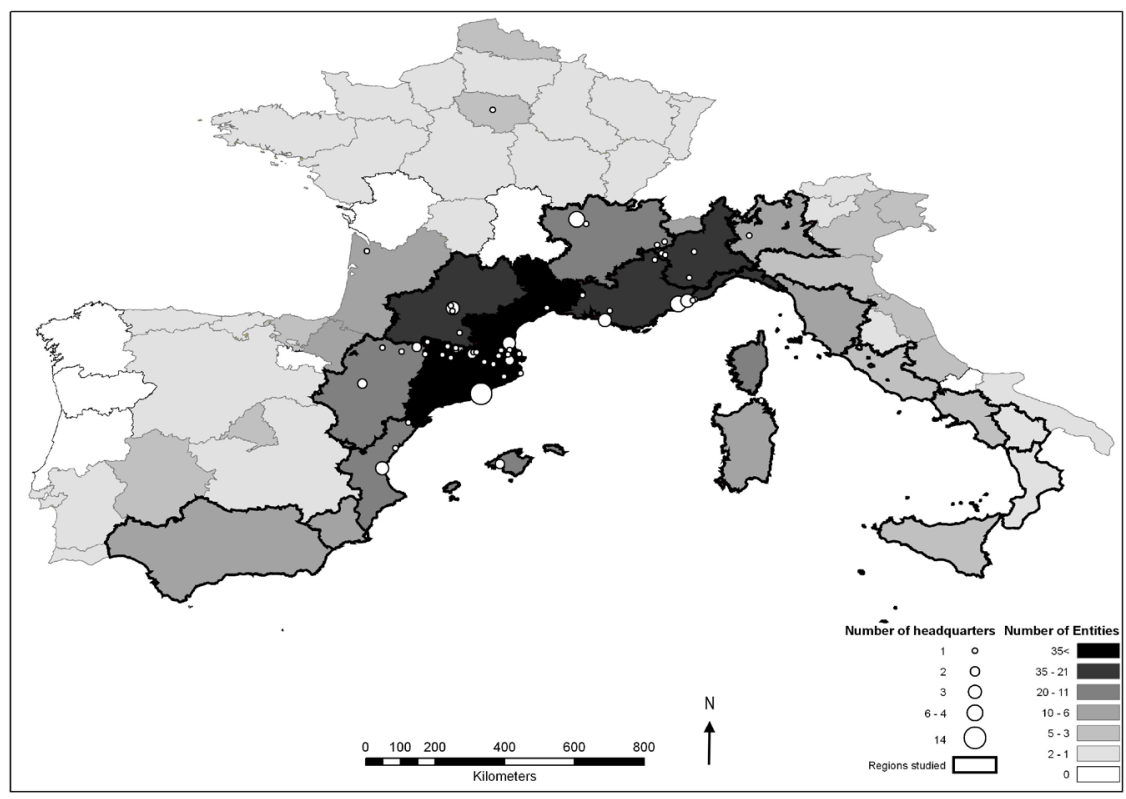

Figure 5. Territorial cooperation in the western Mediterranean: involvement of European regions and city by number of entities and headquarters

Source: Durà-Guimerà and Oliveras-González (2013, p.109).

The Intermediterranean Commission (IMC) is a geographical commission of the Conference of Peripheral Maritime Regions (CPMR), which brings together some forty sub-state authorities from Mediterranean countries including the Valencian Community, Catalonia, Occitanie, Sud-PACA ${ }^{7}$ and Tuscany. At the end of 2014, the IMC set up a working group on territorial cooperation and macro-regional strategies in the Mediterranean.

\footnotetext{
${ }^{6}$ One of Europe's leading technology parks, Sophia-Antipolis was founded in 1969 around the idea of crossfertilization between research, teaching and industry. Located in Côte d'Azur, northwest of Antibes and $20 \mathrm{~km}$ from Nice airport, the park accommodates more than 2,000 companies employing around 36,000 people, along with 4,000 researchers and 5,000 students.

${ }^{7}$ Despite the Regional Council adopted the name Région Sud Provence-Alpes-Côte-d'Azur in 2018, and since then often only uses the term 'Sud' in many marketing and branding operations, the official name remains Region Provence-Alpes-Côte-d'Azur (PACA). Indeed the regional authorities have considered so far that modifying the national law to officially replace the name would be a too complicated and heavy process.
} 
Moreover, we find several organisations specifically at the macro-regional scale (Table 3, Fig. 6). The inter-state forum Dialogue 5+5, created in 1990 between Spain, France, Italy, Malta, Portugal, Algeria, Libya, Morocco, Mauritania and Tunisia, is the oldest body linking the countries of the two shores of the Mediterranean. It is an active sub-group within the UfM. The forum has set up a Group of transport ministers of the western Mediterranean (GTMO 5+5), which is monitored by the CETMO (Centre for transportation studies for the Western Mediterranean) based in Barcelona. Also in Barcelona is the headquarters of the Latin Arc, an association between coastal territorial authorities at NUTS 3 level: Spanish and Italian provinces, Italian metropolitan cities and French départments.

Table 3. Macro-regionalisation in the western Mediterranean: players and bodies

\begin{tabular}{|c|c|c|}
\hline Type & Organisations & Complementary schemes \\
\hline Sub-regional / inter-state & $\begin{array}{l}\text { 5+5 Dialogue en Méditerranée } \\
\text { occidentale }\end{array}$ & \multirow{4}{*}{$\begin{array}{l}\text { Union for the Mediterranean } \\
\text { Plan Bleu } \\
\text { Mediterranean policies } \\
\text { of France, Italy or Spain } \\
\text { EU Neighbourhood Policy } \\
\text { Anna Lindh Foundation } \\
\text { Euroregion Pyrenees-Mediterranean } \\
\text { Euroregion Alps-Mediterranean } \\
\text { Euroregion Andalusia-Algarve-Alentejo } \\
\text { INTERREG Alcotra (France/Italy) } \\
\text { INTERREG Poctefa (France/Spain) } \\
\text { Association } 4 \text { Motors for Europe }\end{array}$} \\
\hline Interregional / sub-state & $\begin{array}{l}\text { Intermediterranean commission of } \\
\text { the Conference of peripheral maritime } \\
\text { regions } \\
\text { Latin Arc } \\
\end{array}$ & \\
\hline $\begin{array}{l}\text { INTERREG } \\
\text { transnational programmes }\end{array}$ & $\begin{array}{l}\text { Mediterranean } \\
\text { Sudoe - South West Europe } \\
\text { Alpine space }\end{array}$ & \\
\hline Sea basin regional strategy & West-Med Initiative & \\
\hline
\end{tabular}

Source: own elaboration.

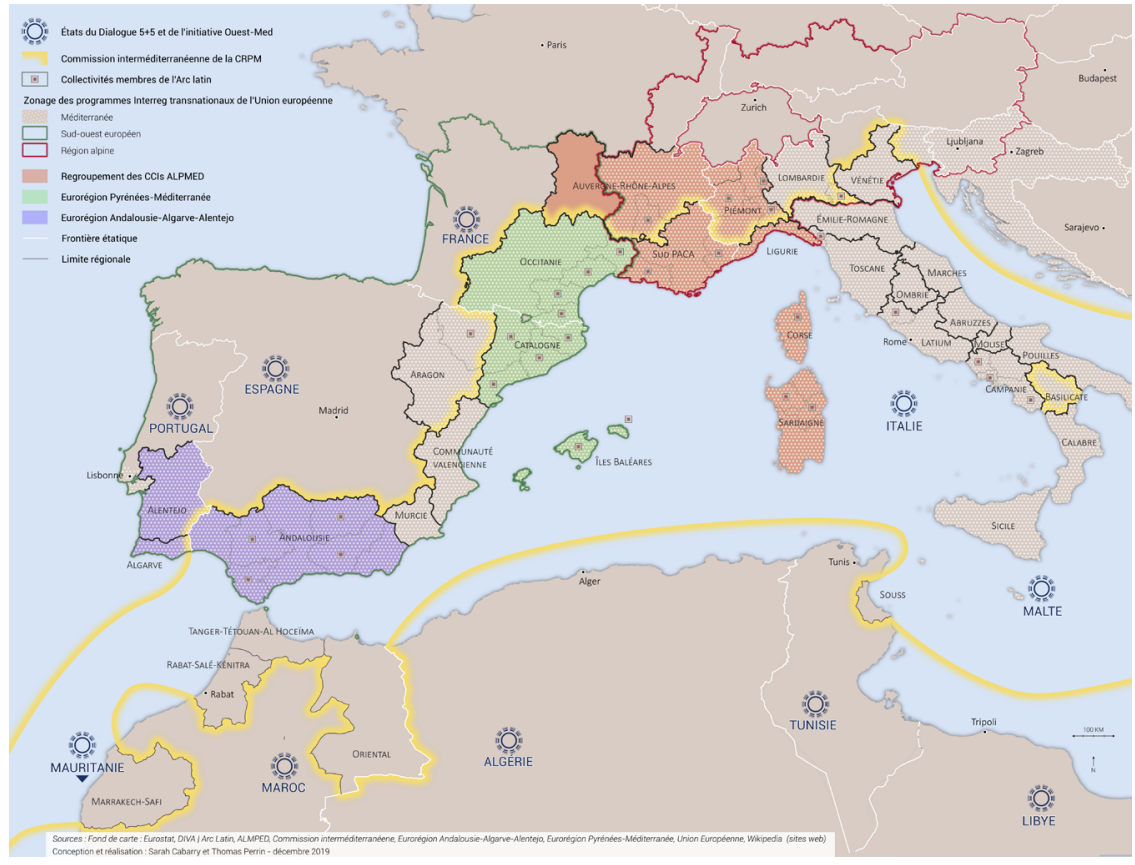

Figure 6. Macro-regional cooperation in the western Mediterranean Source: design and production S. Cabarry and T. Perrin. 
In addition, several EU transnational INTERREG programmes can support macro-regional cooperation, in particular the Mediterranean (MED) programme. For example, within this programme several actors from the western Mediterranean participate in the Panoramed platform that aims at strengthening governance and cooperation capacities in the Mediterranean, in particular by reinforcing complementarities between tools, funding sources and stakeholders. It is worth noticing here that from 2008 to 2011 an INTERREG MED project - Medgovernance was led by the Tuscany region and involved five other western Mediterranean regions and other stakeholders from the area. It studied a new and efficient regional governance system for the area and macro-regional cooperation was already on the agenda of this project. In addition, the transnational programmes Alpine Region and South-West Europe include some territories of the western Mediterranean. Stakeholders can also mobilise INTERREG resources from four cross-border programmes in the macro-region: Alcotra (France-Italy), Poctefa (France-Spain), Maritime France-Italy and the cross-border programme of the Southern European Neighbourhood Policy.

Macro-regionalisation entered a new phase with the launch of the West-Med initiative by the $\mathrm{EC}$ and the 5+5 Dialogue in April 2017. Following the example of other sea basin strategies, the initiative mainly addresses the challenges of sustainable development of the blue economy in the western Mediterranean: pollution, coastal urbanisation, traffic safety. In December 2018, the initiative had enabled eight projects to receive a total of around 7.6 million euro funds to cooperate in the field of sustainable fisheries, in maritime training institutes and academies, forest restoration, maritime planning for security, for example. The EC also granted an additional 1.4 million euro support facility to boost this initiative. The Commission will report on this initiative to the European Council and the European Parliament by 2022. A critical issue is South-North immigration, whose management problems feed growing popular scepticism towards the EU and the emergence of anti-EU and xenophobic movements in many member states.

The West-Med initiative presents macro-regional characteristics in several respects. It results from a multi-level governance dynamic: EC, states and sub-state authorities. The initiative also illustrates a soft space approach with a variable delimitation and 'no predefined territoriality, it is more flexible', as one interviewee points out. Its implementation follows issues or topics that do not necessarily involve all partners or territories. New partners can join the initiative if necessary. The objectives of coordinating and streamlining existing policies and programmes is also found in this space (EC, 2017).

Among the sub-state stakeholders, we can notice that three regions located in the core western Mediterranean zone are particularly involved in territorial and macro-regional cooperation: Catalonia and the French regions of Sud-PACA and Occitanie (Table 4). Catalonia and the region Sud-PACA co-chair the IMC working group on macro-regional and territorial cooperation in the Mediterranean. These regions are also involved in Euroregions that complete the cooperative network at two nodal points of the western Mediterranean: Catalonia in the Euroregion Pyrenees-Mediterranean and region Sud-PACA in the Euroregion Alps-Mediterranean (Perrin, 2015).

The cooperation dynamics in the western Mediterranean thus indicate a certain macro-regionalisation process. In order to further assess these results, the following parts discuss different variables so as to better grasp the policy effect or the spatial effect linked to macro-regionalisation in the area: on the one hand, the stakeholder's involvement and the multi-level interactions; on the other hand, the relation between the planning rationale and its operational implementation. 
Table 4. Involvement of the 'regional triad' of the core western Mediterranean

\begin{tabular}{|c|c|c|}
\hline Catalonia & Sud & Occitanie \\
\hline $\begin{array}{l}\text { Barcelona main West Mediterranean } \\
\text { port (geo-historical) } \\
\text { Mediterranean tropism in the Catalan } \\
\text { government's cooperation and external } \\
\text { strategies } \\
\text { Barcelona headquarters of } \\
\text { organisations: Union for the } \\
\text { Mediterranean, GTMO 5+5, CPMR } \\
\text { Intermediterranean Commission, } \\
\text { Latin Arc, Association of chambers } \\
\text { of commerce and industry of the } \\
\text { Mediterranean (ASCAME), European } \\
\text { Institute of the Mediterranean (IEMed), } \\
\text { Partnership for research and innovation } \\
\text { in the Mediterranean Region (PRIMA) } \\
\text { February 2019, Barcelona: } \\
\text { - Catalonia Mediterranean Forum and } \\
\text { launch of the Mediterranean Strategy } \\
\text { MedCat 2030 for the European Union's } \\
\text { regional policy after 2020 } \\
\text { - Signature of the Mediterranean } \\
\text { Cooperation Alliance (CIM, Pyrenees- } \\
\text { Mediterranean Euroregion, MedCities, } \\
\text { Latin Arc and Adriatic-Ionian } \\
\text { Euroregion) }\end{array}$ & $\begin{array}{l}\text { National scope strategy: planning } \\
\text { operation Euroméditerranée for } \\
\text { the urban renewal of Marseille } \\
\text { (1995), high-speed train line } \\
\text { Méditerranée (2001), European } \\
\text { capital of culture Marseille- } \\
\text { Provence (2013) } \\
\text { Managing authority for the } \\
\text { INTERREG Mediterranean } \\
\text { programme 2007-2013 and } \\
\text { 2014-2020 } \\
\text { External relations focused on } \\
\text { Europe and the Mediterranean; } \\
\text { region 'gateway to a new } \\
\text { Mediterranean diplomacy' (SUD, } \\
\text { 2020) } \\
\text { 2018-2019: 'Mediterranean } \\
\text { Meetings for the future' to } \\
\text { promote cooperation and } \\
\text { 'design the Mediterranean of } \\
\text { tomorrow'(SUD, 2020) } \\
\text { June 2019, Marseilles: Summit } \\
\text { of the two shores of the 5+5 } \\
\text { Dialogue to relaunch cooperation } \\
\text { in the western Mediterranean }\end{array}$ & $\begin{array}{l}\text { Languedoc-Roussillon: one of the } \\
\text { first regions to sign a cooperation } \\
\text { agreement with Catalonia (1980s) } \\
\text { Redevelopment of Montpellier } \\
\text { as a Euro-Mediterranean } \\
\text { technopolis (1980s) } \\
\text { Implications of Midi-Pyrénées } \\
\text { and Languedoc-Roussillon in the } \\
\text { Euroregion with Catalonia from } \\
\text { the 1990s onwards } \\
\text { 2017: opening of the new } \\
\text { Occitanie European House in } \\
\text { Brussels, the president of region } \\
\text { mentions the strategic relations } \\
\text { with Spanish, Italian and North- } \\
\text { African regions in the scope of a } \\
\text { Western Mediterranean macro- } \\
\text { region } \\
\text { 2018: first International } \\
\text { Mediterranean Meetings; } \\
\text { organisation of training courses } \\
\text { for civil servants of the Southern } \\
\text { Mediterranean countries at } \\
\text { the Maison de l'Occitanie in } \\
\text { Casablanca }\end{array}$ \\
\hline
\end{tabular}

Source: own elaboration.

\section{Multi-level interactions and interferences: state rescaling and resilience, persistence of politics parameters}

The situation in the western Mediterranean confirms that sub-state authorities are important agents of macro-regionalisation. Pooling resources and voices of the regions within the IMC working group on territorial cooperation and macro-regional strategies in the Mediterranean contributed to the launch of the West-Med Initiative (WMI). Interviewees relate that representatives of regions or major urban agglomerations have been actively involved in the initiative from the beginning. The involvement of the EC, in particular the DG Mare and DG Regio, was also a key variable in the establishment of the WMI. This path evokes the Adriatic and Ionian maritime strategy which, from 2012 to 2014, preceded the EUSAIR macro-regional strategy (Cugusi \& Stochierro, 2016), with a key political entrepreneurship from the Italian region of Marche. These facts raise the assumption that the transition from a maritime initiative to a macro-regional strategy is likely to occur in the western Mediterranean.

However, different actors are rather doubtful about this outlook: '[a macro-regional strategy] is not a subject (...) the dynamics are different (...) not enough added value to justify a macro-regional strategy'; 'the macro-regional strategy will never happen, it is too complex'. Although they recognise that '[the WMI] can help to establish a macro-regional strategy', they stress that the implementation of a maritime initiative is already a long and difficult process in itself. Other actors are also rather critical about the concrete outcomes of the transition from maritime cooperation to a macro-regional strategy in the Adriatic and Ionian macro-region. 
The case study also challenges the assumption that euroregional organisations are systematic key players in macro-regionalisation. Situations appear to be more variable. For example, the Alps-Mediterranean Euroregion has been inactive for several years, mainly due to political disagreements or lack of interest from member regions. However, the same regions have been involved since 2014 in the EU strategy for the Alpine macro-region (EUSALP). This can be interpreted as an opportune - not to say opportunist - prioritisation of their common issues relating to the Alpine space, in comparison to those of the Mediterranean. We can notice here that the reform of the regions in France has merged the Rhône-Alpes region with Auvergne, another mountainous territory. In the Pyrenees-Mediterranean Euroregion, Occitanie and Catalonia have clearly affirmed their Mediterranean strategies. But Occitanie has a limited capacity according to the French territorial organisation. In Catalonia, the long-standing and controversial socio-political relationship with the Spanish state reached a breaking point in October 2017, when the Catalan government held a referendum on independence that was not authorised by the Spanish state. Some Catalan politicians were imprisoned, others had to flee to other European countries. The outcome of this crisis is uncertain and questions the evolution of regionalism and state rescaling in the context of the EU (Kölling, 2019). For instance, among diverging and sometimes disrupting interpretation of the situation, some observers estimate that Catalonia, like other regions that claim independence in UK or Belgium, already meets all the chapters of the acquis communautaire in their entirety, and they ask what would prevent them from joining the EU very quickly after independence. In the same vein others argue why these regions would not keep the Euro currency when Montenegro has it de facto without being a member of the EU nor of the Eurozone. On the whole this conflict shows a tension between rule of law and right to self-determination and between the respective weight of political or legal arguments in this debate.

The objective here is not to deal with this quite unprecedented situation, which would require a dedicated paper, but rather to indicate how it is likely to hamper macro-regionalisation projects in the western Mediterranean. Macro-regional cooperation is also a way for sub-state authorities to project their capacity beyond the state domain (Gänzle \& Kern, 2016, p.9) and in this sense Catalonia is a key advocate of macro-regionalisation (see Table 4). But in Spain the state remains the managing authority for most of the 2014-2020 European structural funds and retains control over other European policies that have major planning implications. For instance, the development of a high-speed rail link in the Spanish Mediterranean corridor is actively promoted by Catalonia and the Valencian Community and included in the Mediterranean Corridor supported by the EU Trans-European Transport Network policy. Yet, despite the existence of the Group of Transport Ministers for the western Mediterranean, this major infrastructure project faces rather slow implementation and divergent state priorities (Boira Maiques, 2010; Boira Maiques \& Prytherch, 2015).

Nevertheless, indicators evolve. In 2018 the Spanish government installed a Commissioner for the development of the Mediterranean corridor, in partnership with the Valencian Community, and appointed the geographer Josep Boira Maiques to this post. As his work mentioned above shows, this former transport and infrastructure adviser to the Valencian Community has always worked to defend and promote this transport connection. Moreover, the launch of the Cat Med strategy in 2019, in which the regions of the area and the Pyrenees-Mediterranean Euroregion were clearly involved, may mark a new turning point in the dynamics of cooperation in the western Mediterranean. With regard to French-Italian cross-border cooperation, we also observe that several cooperative organisations exist beyond the Alps-Mediterranean Euroregion, such as an AlpMed Euroregion between the Chambers of commerce and industry, which was reactivated while the political Euroregion fell into inactivity (see Fig. 6). 
Thus the case of the western Mediterranean confirms that macro-regionalisation, beyond the planning logic, strongly depends on politics parameters among which the states keep a preponderant influence. The WMI shows a path development 'from the states back to states' as one of the interviewees said. It was initiated by the inter-state framework of the $5+5$ Dialogue, and although the EC pushed its effective implementation, the 5+5 Dialogue finally (re)took the lead. Even if the regions are involved in designing the contents and activities of the WMI, the steering committee is made up of state representatives. Similarly, only state representatives have decisional vote within the Panoramed governance platform mentioned above. One actor stated: 'we must use geometries that correspond to the will of the state', and another interprets the launch of the WMI as 'a kind of response to the aspiration to create a macro-regional strategy'.

In many respects, macro-regional strategies, which represent the most elaborate form of macro-regionalisation, remain sub-diplomatic rather than inter-regional frameworks for cooperation, in which the diplomatic departments of member states maintain close control. The strategies must be approved by the member states in the EU Council. Despite lobbying by several sub-state authorities of the Atlantic Arc, a strategy has not been adopted so far due to the reluctance of the concerned states. In this sense, the classic forms of sub-regional cooperation, despite their a priori dated nature, have a certain role to play in macro-regionalisation. The role of the $5+5$ Dialogue in the western Mediterranean, or the importance of the Nordic Councils action in the Baltic Sea macro-regionalisation, corroborate this assessment.

Politics parameters also concern relations between sub-state authorities, which can vary according to majorities and political lines, changing commitments or political contingencies, as shown by the case of the Alps-Pyrenees Euroregion. Moreover, there is not the same degree of political decentralisation between the northern and southern shores of the western Mediterranean, which strengthens the position of the states, although we can observe that Morocco, which has been engaged in a process of regionalisation since its constitutional reforms in 2011, is currently associated with the region Occitanie for the training of regional officials.

These governance issues raise a recurring dilemma in regional planning, and a fortiori in macroregional planning: territorial projections often follow a relational and networked approach, while policy implementation is linked to administrative boundaries (Seltzer \& Carbonell, 2011, p.6-12).

\section{Tension between spatial projection and planning policies: what limits for the Western Mediterranean}

The analysis of the western Mediterranean macro-regional cooperation shows how the soft space planning approach can face realpolititk. Even if in the EU discourse the external dimension represents an important asset of macro-regional strategies, in order to better connect and articulate the European space with the neighbourhood areas, the western Mediterranean macro-region appears to be, in several ways, 'too open to function'.

We find here an (additional) indicator of the hazards of the Euro-Mediterranean cooperation. The UfM was expected to mark a new beginning after the failure of the Barcelona Process, the first Euromed cooperation initiative launched in 1995. So far, the achievements of UfM are rather limited in view of the geopolitical, social and environmental situation in many parts of the Mediterranean, including war, growing inequalities and migration-related tensions. Moreover, since its inception the UfM has suffered from a lack of consensus among EU member states. In particular, there is a Franco-German tension over the priority to be given to the southern flank of the EU. 
EU enlargement to the east has altered spatial and political balances to Germany's advantage, whereas the Mediterranean is a traditional zone of influence for France. The initial project of the UfM, drafted by France, included only the coastal countries of the basin ${ }^{8}$, but in the end Germany obtained that all EU member states be part of the UfM.

Moreover, several observers consider that the implementation of macro-regional cooperation is particularly challenging in such an unstable and discontinuous space (EP, 2015; Cugusi \& Stocchiero, 2016, p.184; Scott et al., 2019). For instance the Mediterranean cross-border programme of the 2014-2020 Neighbourhood Policy has been delayed for political reasons and the first call for projects was only launched in July 2017. We can also mention here the relatively confidential impact of the Medgovernance project's outputs, delivered in 2011. Other observers even argue that the rationale of a Mediterranean macro-regionalisation conveys an ambiguous technocratic fantasy and that the discourse on soft space can serve a strategy of EU rebordering, of borders reassertion in order to both export the EU's political priorities and better demarcate its southern limits (Bialasiewicz, Giaccaria, Jones \& Minca, 2013). This assessment accords with the 'evidence of the highly selective nature of EU conceptualisations of neighbourhood relations and Mediterranean space. These conceptualisations generally share the ambivalent tendency to consider the sea as a region, on the one hand, and to see it as a border, on the other' (Scott et al., 2019, p.6).

Given these potential deadlocks, an alternative outlook to macro-regionalisation could be to elaborate and implement a strategy for the North-western Mediterranean regions, in order to strengthen and rationalise territorial cooperation without limiting it to maritime issues. Such a mapping would be consistent with the existing cooperative dynamics. However, various stakeholders refute the operational added value of this outlook: a North-South partition of the Mediterranean has no relevance a fortiori if the objective is to cooperate. Euro-Mediterranean cooperation is therefore in a particularly ambivalent situation which can only inhibit its development. A 'soft consensus' on the urgency to cooperate is the actual only response to serious socio-economic and political fragmentations, while its concrete realisation faces constant criticism or disagreement on the validity or the significance of this cooperation.

In this situation, the WMI provides an appropriate scheme to cooperate in such a fragmented area, the sea being the best - or most reasonable - common denominator, which is in line with the idea that 'the Mediterranean could potentially mean new spaces for political interaction and socio-cultural dialogue on multiple scales, especially if they facilitate jointly negotiated cooperation around common concerns' (Scott et al., 2019, p.7). One actor believes that 'the northern and southern shores talk to each other, and that is already a great deal'. In this sense the choice of a maritime strategy can be interpreted as a means of circumscribing the field of cooperation to the sea, thus avoiding potentially conflicting territorial issues in the rea $^{9}$. The $\mathrm{WMI}$ is thus expected to cope with the sea-related features and challenges of the macro-region such as environmental protection, the pressure of touristic activities on the ecosystems or the competition for natural resources. Yet once again, the persistent weight of state relations in the development of the strategy questions the potential role and implication that the insular regions could take in the process. Sardinia, Corsica or Balearic Islands all benefit from specific regional status and capacities within their respective states, but do not show any specific involvement in the WMI so far compared to the other sub-state stakeholders.

\footnotetext{
${ }^{8}$ As well as Portugal, Jordania and Mauritania.

${ }^{9}$ One can think of the Western Sahara issue between Morocco and Algeria, the tensions between Morocco and Spain over the cities of Ceuta and Melilla, or the problems between European and North African states over migratory flows (Scott et al., 2019).
} 
Besides the sea-territory dialectic, another spatial planning issue that the case study raises is the compartmentalisation of the Mediterranean. Indeed, the date and information collected show that having several macro-regional areas in the basin can be a response to operationalise cooperation on a scale that is more effective than the global, but so far dysfunctional, scale of the UfM. However, as the debates at the MedCat Forum in February 2019 showed, opinions remain divided between a strategy for the whole Mediterranean, several Mediterranean strategies or cooperation based on more specific arrangements with variable composition and delimitation. Such debates reaffirm the importance of politics parameters. In this perspective, the implementation of EU INTERREG programmes after 2020, with the project to align programmes with macro-regional or sea basin strategies, will be a key variable to analyse in the western Mediterranean cooperation.

Furthermore, initiatives for macro-regionalisation of the western Mediterranean confirm that certain planning issues and problems can only be addressed at new scales, distinct from traditional administrative boundaries and involving co-operative governance. They illustrate how European integration can influence planning priorities and methods. But they also reveal some contradictions of the 'Europeanisation injunctions'.

Generally speaking, the macro-regional dynamics indicate an evolution towards a political context that we consider 'post-complex'. The EU is a complex system of intertwined prerogatives, mobile societies and interconnected flows of people and goods. Macro-regional strategies, with their multi-partner, flexible and cooperative logic, embody an attempt to 'operate the complex', to mobilise and organise the various resources of complexity in order to develop more effective and legible policies. As one interviewee put it: 'the objective is the outcome, not the bureaucratic element or eligibility'. But the question remains open as to how flexibility and coherence can match. How can stakeholders, and even more so citizens, identify a certain policy or organisation if the incumbents and the territorial scope may vary from one project to another? Can macro-regional arrangements gain institutional depth without creating new institutions? We find here the limit of the soft space approach and the limited operability of opposing soft and hard spaces to interpret macro-regional contexts (Boulineau, 2017). At a certain point it seems necessary to clearly delimit actions, domains or fields of application in order to achieve effective policies and give them sense. It seems difficult for strategic planning to simply add up projects with variable geometry, unless it is strategic only by name.

This shift towards post-complexity can also be interpreted as part of a more general attempt to reduce the gap between citizens and EU policies, to show the added value of EU concrete achievements in everyday life. With macro-regional strategies, the EU seeks to renew territorial cooperation at appropriate scales and through appropriate modalities to address concrete problems, which could not be dealt with at national, regional or local level. Simplification, flexibility, synergies, communication and visibility are among the key objectives of EU regional policy announced for 2021-2027. In the macro-regions we can notice the objective to increase communication strategies and to organise events and activities. While these objectives may sound like 'rhetoric as usual' of each new programming period, it may be time to seriously achieve them as they relate to shared and salient issues in open, democratic and plural societies: how to reconcile social complexity and policy effectiveness without false simplification, how to bring citizens closer to their representatives without gross demagoguery.

However, if the rationale of macro-regionalisation is clear, the effects remain questionable. In many ways the macro-regional framework resembles another intergovernmental organisation, an additional layer of rotating presidencies and confidential annual meetings. While the EU lines for regional policy after 2020 indicate a certain normalisation of macro-regional cooperation, a 
'macro-regional fatigue' cannot be excluded in some cases depending on the politics parameters, on the achieved results and on the different stakeholder's policy priorities.

\section{Conclusion}

The case of the western Mediterranean sheds light on the various potentialities and deadlocks of macro-regionalisation. This type of territorial co-operation, although complex and sometimes disordered, can be a relevant planning instrument in today's European space. The western Mediterranean presents social, economic or political indicators that can favour macro-regional cooperation, especially if we consider the intensity of territorial cooperation in the area. A maritime initiative for the western Mediterranean was launched in 2017 and marks a step to structure macro-regionalisation. Several political actors in the region advocate a deepening and reinforcing of macro-regional cooperation, in order to better organise the blue economy, to develop better transport infrastructure or economic synergies, among others. At the same time, the western Mediterranean reveals a fragile and tense geopolitical context, with in particular a marked socio-political fragmentation between countries and territories of the northern and southern shores. This situation somewhat limits macro-regional cooperation to maritime issues, which appear to be the only reasonable common denominators so far. Yet, completing a macro-regional strategy on the bases that were unraveled in this paper can allow a better streamlining of the multiple cooperation initiatives in the area, so as to implement focused solutions to the most salient regional planning and development issues. Thus, the case of the western Mediterranean questions the possibility of achieving macro-regionalisation without a macro-regional strategy sensu stricto. Further comparative studies can provide additional outlook to better grasp this aspect of macro-regionalisation.

Moreover, this case study illustrates how macro-regionalisation is part of a more general trend of spatial Europeanisation, in which the EU territorial cooperation mechanisms draw a new European cartography that transcends the 'Westphalian' state borders. Mapping and developing transnational ensembles such as macro-regions contribute to redefine territorial representations and, consequently, to a renewal of European meta-geography. By combining different scales of regionalisation, from local to global, macro-regionalisation suggests that the construction of interstate 'macro' regional organisations and the development of sub-state and transnational 'micro' regions are dialectic and interdependent processes that complement, rather than oppose to, the socio-spatial formation of nation states. On the ground, the current macro-regional dynamics indicate a quest for an appropriate policy response to the challenges of a contemporary 'post-complexity', so as to combine complexity and efficiency, diversity and rationalisation. And to show the added value and relevance of the EU as a political entrepreneur. In a way, it evokes the critical challenge of the EU that is to form a common demos from several specific nations and cultures, without replacing them (Menasse, 2015).

Despite cooperative discourses and injunctions, politics parameters - particularly at the level of states and territorial authorities - still condition the effectiveness of macro-regional arrangements. This limitation parallels some of the impasses in EU governance. Moreover, popular participation remains weak in macro-regional achievements, which may hinder any improvement of the reception and comprehension of EU policies and representations. Moving from a mere functional to a more socio-cultural embodiment of macro-regionalisation may be a step to take forward if the agenda of spatial Europeanisation remains topical, and the revision of EU Territorial Agenda that must be completed by 2021 is an opportunity to reconsider such outlook. 


\section{References}

Albrechts, L., Healey, P., \& Kunzmann, K. (2003). Strategic Planning and regional governance in Europe. Journal of American Planning Association, 69(2), 113-129. https://doi.org/10.1080/01944360308976301

Allmendinger, P., Chilla, T., \& Sielker, F. (2014). Europeanizing Territoriality. Towards Soft Spaces? Environnement and Planning A, 46(11), 2703-2717. https://doi.org/10.1068/a130037p

Baudelle, G., Guy, C., \& Ollivro, J. (2002), Les scénarios de l'espace européen. In G., Baudelle \& B., Castagnède (Eds.). Le Polycentrisme en Europe. Une vision de l'aménagement du territoire européen (pp. 107-154). La Tour d'Aigues/Paris : Éditions de l'Aube/DATAR.

Bellini, N, \& Hilpert, U. (Eds.). (2013). Europe's Changing Geography. The Impact of Inter-regional Networks. London: Routldedge.

Bialasiewicz, L., Giaccaria, P., Jones, A., \& Minca, C. (2013). Re-scaling 'EU'rope: EU macro-regional fantasies in the Mediterranean. European Urban and Regional Studies, 20(1), 59-76. https://doi. org/10.1177/0969776412463372

Boira Maiques, J-V. (2010). L’Eix Mediterrani entre les dinàmiques locals i la perspectiva megaregional. Documents d'anàlisi geogràfica, 56(1), 91-109.

Boira Maiques, J-V., \& Prytherch, D. (2015). Mediterranean regionalism from territory to trains: spatial politics and planning of macro-regions and transport networks in Spain. Space and Polity, 19(2), 110131. https://doi.org/10.1080/13562576.2015.1050844

Boix, R., \& Marull, J. (Eds.). (2016). Megaregions i desenvolupament urbà sostenible. Factors estratègics per a l'àrea metropolitana de Barcelona en el context europeu. Papers. Regió Metropolitana de Barcelona: Territori, estratègies, planejament, 58. Retrieved from https://iermb.uab.cat/wp-content/ uploads/2016/12/Papers-58-web.pdf

Boulineau, E. (2017). Les macrorégions en Europe, une nouvelle régionalisation pour renforcer la cohésion territoriale ? In G., Baudelle \& G., D., Charles-Le Bihan (Eds.). Les régions et la politique de cohésion européenne (pp. 95-108). Rennes : Presses Universitaires de Rennes.

Brenner, N. (2004). New States Spaces. Urban Governance and the Rescaling of Statehood. Oxford: Oxford University Press.

Brunet, R. (Ed.). (1989). Les Villes 'européennes'. Montpellier-Paris: Datar-Reclus, La Documentation française.

CEC (1991). Europe 2000: Outlook for the Development of the Community's Territory. Commission of the European Communities. Luxembourg: Office for Official Publications of the European Communities.

Courtot, R., Daviet, S., \& Joannon, M. (Eds.). (1994). L’Arc méditerranéen en questions. Méditerranée, 79(1-2), pp. 87.

Cugusi, B., \& Stocchiero, A. (2016). The European Union Strategy for the Adriatic-Ionian Region. In S., Gänzle \& K., Kern (Eds.). A 'Macro-regional' Europe in the Making. Palgrave Studies in European Union Politics (pp. 169-188). London: Palgrave Macmillan. https://doi.org/10.1007/978-1-13750972-7 8

Dühr, S. (2018). A Europe of 'Petites Europes': an evolutionary perspective on transnational cooperation on spatial planning. Planning Perspectives, 33(4), 543-569. https://doi.org/10.1080/02665433.201 8.1483262

Durà-Guimerà, A., \& Oliveras-González, X. (2013). A Typology of Agents and Subjects of Regional Cooperation: The Experience of the Mediterranean Arc. In N., Bellini \& U., Hilpert (Eds.). Europe's Changing Geography. The Impact of Inter-regional Networks (pp.101-124). London: Routledge.

EC (2017). Communication from the Commission to the European Parliament, the Council, the European Economic and Social Committee and the Committee of the Regions: Initiative for the sustainable development of the blue economy in the western Mediterranean. COM/2017/0183. Brussels.

EESC (2012). Opinion of the European Economic and Social Committee on 'Developing a macro-regional strategy in the Mediterranean - the benefits for island Member State. European Economic and Social Committee. Retrieved from https://www.eesc.europa.eu/en/our-work/opinions-information-reports/opinions/macro-regional-strategy-mediterranean 
EP (2012). Resolution of 3 July 2012 on the evolution of EU macro-regional strategies: present practice and future prospects, especially in the Mediterranean. European Parliament, P7_TA(2012)0269.

EP (2015). New Role of Macro-Regions in European Territorial Cooperation. Brussels: European Parliament. Retrieved from http://www.europarl.europa.eu/studies

Eurostat (2019). Eurostat regional yearbook 2019. Luxembourg: Publications Office of the European Union.

Florida, R., Gulden, T., \& Mellander, C. (2008). The rise of the mega-region. Cambridge Journal of Regions, Economy and Society, 1(3), 459-476. https://doi.org/10.1093/cjres/rsn018

Gänzle, S., \& Kern, K. (Eds.). (2016). A 'Macro-regional' Europe in the Making. Theoretical Approaches and Empirical Evidence. Basingstoke: Palgrave Macmillan. https://doi.org/10.1007/978-1-13750972-7

Gulden, T. \& Morris, R. (2020). Who's your city. Maps. Retrieved from http://www.creativeclass.com/_ v3/whos_your_city/maps/\#Mega-Regions_of_Europe

Jones, M., \& Paasi, A. (2013). Guest Editorial: Regional World(s): Advancing the Geography of Regions. Regional Studies, 47(1), 1-5. https://doi.org/10.1080/00343404.2013.746437

Juan, J.-C. (1994). L’arc méditerranéen: un espace en devenir. Méditerranée, 79(1-2), 7-14.

Kölling, M. (2019). The Catalan secession bid. Between structural and contemporary tensions within the State of Autonomies. In G., Abels \& J., Battke (Eds.). Regional Governance in the EU. Regions and the Future of Europe (pp. 88-105). Cheltenham: Edward Elgar. https://doi. org/10.4337/9781788978620.00014

Leloup F., Moyart L., \& Pecqueur B. (2005). La gouvernance territoriale comme nouveau mode de coordination territoriale ? Géographie, économie, société, 7(4), 321-332. https://doi.org/10.3166/ ges.7.321-331

Lever, W. (1999). Competitive Cities in Europe. Urban Studies, 36(5-6), 1029-1044. https://doi. org/10.1080/0042098993349

Medeiros, E. (2013). Euro-Meso-Macro: The New Regions in Iberian and European Space. Regional Studies, 47(8), 1249-1266. https://doi.org/10.1080/00343404.2011.602336

Medeiros, E. (2018). The Role of European Territorial Cooperation (ETC) in EU Cohesion Policy. In E., Medeiros (Ed.). European Territorial Cooperation (pp. 245-265). Berlin: Springer.

Menasse, R. (2015). Un messager pour l'Europe. Plaidoyer contre les nationalismes. Paris: Buchet Chastel.

Nagler, A. (2013). European Macro-Regions as a New Dimension of European Geography: Networks of Collaboration in the Light of Culture, History and Language Capabilities. In N., Bellini \& U., Hilpert (Eds.). Europe's Changing Geography. The Impact of Interregional Networks (pp. 31-63). London, New York, NY: Routledge.

Perrin, T. (2015). Creative regions on a European cross-border scale: policy issues and development perspectives. European Planning Studies, 23(12), 2423-2437. https://doi.org/10.1080/09654313.2 014.988017

Perrin, T. (2019). Cultural dimension of macro-regions. A prospective reflection. In G., Abels \& J., Battke (Eds.). Regional Governance in the EU. Regions and the Future of Europe (pp. 159-175). Cheltenham: Edward Elgar.

Perrin, T. (2020). Refaire région. Pour une reconsidération de la région en aménagement. Mémoire d'habilitation à diriger des recherches, volume II - Position et projet scientifique. Université de Perpignan-Via Domitia - URM ART-Dev.

Rivière, D. (2005). L'Arc méditerranéen, un 'objet européen' à la recherche de son identité. Actes du Festival International de Géographie de Saint-Dié-des-Vosges. Retrieved from http://archives-fig-st-die. cndp.fr/actes/actes_2005/index.htm

Scott, J. W., Celata, F., \& Coletti, R. (2019). Bordering imaginaries and the everyday construction of the Mediterranean neighbourhood. European Urban and Regional Studies 26(1), 3-8. https://doi. org/10.1177/0969776418795208

Seiler, D-L. (2004). Comparaison et aires culturelles régionales. L'Europe du sud et les modèles de Rokkan. Pôle Sud, 21(2), 69-80. https://doi.org/10.3917/psud.021.0069

Seltzer, E., \& Carbonell, A. (Eds.). (2011). Regional Planning in America. Practice and Prospect. Cambridge: Lincoln Institute of Land Policy.

SUD (2020). Region SUD. Retrieved from https://www.maregionsud.fr/a-la-une/mediterranee-du-futur 
Vanier, M. (2008). Le pouvoir des territoires. Essai sur l'interterritorialité. Paris: Economica.

Wassenberg, B., Reitel, B., Peyrony, J., \& Rubió, J. (2015). Territorial Cooperation in Europe. A Historical Perspective. Luxembourg: Publications Office of the European Union. https://doi.org/10.2776/374386

Zaucha, J., Pyć, D., Böhme, K., Neumann, L., \& Aziewicz, D. (2020). EU macro-regional strategies for the Baltic Sea Region after 2020. A nutshell of beauty and possibilities. Europa XXI, 38, 51-76. https:// doi.org/10.7163/Eu21.2020.38.1 